\title{
An Analysis Of National Culture And Leadership Practices In Indonesia
}

\author{
Dodi Wirawan Irawanto, Brawijaya University, Malang, Indonesia
}

\begin{abstract}
Managers around the world need ideas and support to meet many of the challenges of leading. Leadership requires actions and strategies as well as convictions and ideas. Leadership occurs in relation with followers. Leading Indonesian people is not the same as leading Westerners nor is it the same as leading other Asian people. A leadership strategy effective in one culture can be counter-productive in another. In this paper, the use findings of Hofstede's and the GLOBE's studies are used to identify important values of Indonesians, relating them to Indonesian culture and leadership style in an organization setting. Indonesians emphasis collective well being and show a strong humane orientation within their society. The culture is assertive, and pays attention to maintaining harmony. Effective leaders are expected to show compassion while using a more paternalistic than autocratic leadership style. It is advisable that expatriate managers need to avoid actions that are not suited to these values and expectations.
\end{abstract}

Keywords: National Culture, Organizational Culture, Leadership, Indonesia

\section{INTRODUCTION}

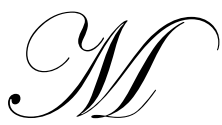

anagers around the world need ideas and support to meet many of the challenges of leading. Leadership requires actions and strategies as well as convictions and ideas. Leadership occurs in relation with followers. Leading Indonesian people is not the same as leading Westerners nor is it the same as leading other Asian people. A leadership strategy effective in one culture can be counter-productive in another. Leadership and organizational culture are purported to be tightly intertwined (Peters and Waterman 2004). Leaders should have a deep understanding of the identity and impact of the culture in order to manage effectively.

Cultural differences both between nations and organizations, are increasingly being debated (Hofstede and Hofstede 2005). This is especially important in studying organizations, because as Lees (2003) pointed out, organizations are at the micro level of the wider culture. Wider culture, as defined by Lees, is related to the national culture. As an operation goes worldwide, a change of cultural practices may take place. It may not be appropriate for the manager of a multinational company to come to a host country and influence the culture of the employee with their own culture. With this in mind it may not be possible to separate the national culture, which is embedded in the host country from management practices. For instance when the Idul Fitri (Moslem New Year in Indonesia) is celebrated, national workforce regulation (UU Ketenagakerjaan) stipulated that all companies including multinational companies have to pay a kind of bonus called THR (Idul Fitri Bonus) equal to one month's salary. The example above shows us how a Moslem custom in a particular country (macro-level) drives the way organizations (micro-level) manage their practices, however micro-level culture is often a reflection of the macro-level cultures; it stands to reason that an organization may be affected by the culture of the community that surrounds it. Furthermore, there may be influences which run continuously between the macro-culture and micro-culture. To be successful, organizations need to establish work value systems that are adapted to the macro-culture in which they operate.

Thus, deeper investigation into the interaction of national culture and organization culture needs to take place to distinguish what are the best practices for organizational effectiveness. This study aimed to investigate the Indonesian's preferences toward organizational culture and leadership practices using secondary data resulted from Hostede's study and Globe project. It is hope, that by looking at this national culture dimensions, academicians and 
business practitioners can enhance their understanding on organizational culture and leadership practices in Indonesian context.

\section{CULTURE DIMENSIONS}

Culture as a part of our social interaction in life is deeply connected to factors of the culture such as symbolism (Lees 2003), family interaction (Trompenaars and Turner 1998), values (House 2004), languages (Bjerke 1999) and in the nations to which we belong. By this, understanding the importance of culture, all of the cultural factors may be linked together. Understanding an organization's culture is to assess that which is shared by individuals within the organization, their beliefs, values, attitudes, and norms of behavior. Organizational culture encompasses the shared meanings that individuals place on their working life, and the narratives they use in making sense of their organizational context. To make organizational rules that are acceptable and legitimate; people need understanding, and the ability to describe and make sense of their working context; the rules act as a kind of social and normative glue.

According to Deal and Kennedy (1982) culture is described as "the way things are done around here". The examination of organizational culture relates directly to what can also be viewed as "large concept", in which Alvesson (2000) argued that culture is like an umbrella concept, for a way of thinking which takes a serious interest in cultural and symbolic phenomena. Thus understanding the complexity of organizational phenomena requires extra attention to be paid to who controls the organization.

Figure 1

National Culture Dimensions Definitions

\section{HOFSTEDE DIMENSIONS}

Power distance : The extent to which the less powerful members of organizations accept and expect that power to be distributed equally.

Individualism and collectivism : The extent to which individuals prefer to act as individual rather than as members of groups.

Masculinity and Femininity : The degree of assertiveness and comprehensiveness versus modesty and caring.

Uncertainty avoidance : The degree to which people prefer structured over unstructured situations

Long term orientation and Short term orientation : Thrift and perseverance versus (short term) respect to tradition, fulfillment of social obligations, and protection of one's "face".

Source : Hofstede, G. H., \& Hofstede, G. J. (2005). Cultures and organizations : software of the mind (2nd ed.). NY, USA: McGraw-Hill

\section{GLOBE PROJECT DIMENSION}

Group/Family collectivism : The degree to which individuals express pride, loyalty, and cohesiveness in their organizational.

Power distance : The degree to which members of a collective expect power to be distributed equally.

Humane Orientation : the degree to which individuals in organization encourage and reward individuals for acts of fairness, altruism, friendliness, generosity, caring, etc.

Uncertainty avoidance : The extent to which a collective relies on social norms, rules, and procedures to alleviate unpredictability of future events.

Institutional collectivism : The degree to which institutional practices encourage and reward collective distribution of resources and collective action.

Future orientation : The degree to which individuals in organizations engage in future-orientated behavior.

Performance orientation : The extent to which an organization encourages and rewards members for performance improvement and excellence

Assertiveness : the degree to which individuals in organizations exhibit and accept assertive, confrontational, and aggressive behavior in social relationship.

Gender egalitarianism : The extent to which an organization minimizes gender differences.

Source: House, R. J. (Ed.). (2004). Culture, leadership, and organizations : the GLOBE study of 62 societies / edited by Robert J. House. CA, USA: Sage Publication 
It is hard to expect what an organization should do in dealing with the culture. Schein (1999) argued that there is no right or wrong culture, no better or worse culture, except in relation to what the organization is trying to do and what the environment is in which it is operating. In concluding the discussion on organizational culture, it may be important to realize how complex the term 'organizational culture' is, however, having looked at Martin's argument (2002) concluding that studying culture is not about the definition at all, it is important to map the culture, hence, the culture represents a wide range of view; the map may not be the territory, but it could be a better map of the larger world of cultural research.

Furthermore, investigation by Hatch and Schultz (1997) has led the organizational researcher toward understanding explicit meaning about organizational culture, and to the specific meaning which emphasizes the context of organizational symbolism. They argued that the concept of organizational culture is also referred to as organizational identity, and image. It is about how the members of an organization feel, behave and think about their organization. Thus, it is how an outside audience sees what our organization is like; it is called image. This concept gives us a clear image on how we must see the more specific content of organizational culture, which enables us to identify and operationalize it in studying organizational culture.

The logical assumption has been that the culture differences may be investigated by looking at the national culture dimensions. Five socio-cultural dimensions, identified by Hofstede from the research in the early 1980's and the nine dimensions of GLOBE Studies from the research in the 1990's are the most cultural dimensions used in the management research, are described in Figure 1. The dimensions proposed by GLOBE study in some sense seem to replicate Hofstede's findings (Triandis 2004; Hofstede 2006). However, the national culture dimensions as shown in figure 1 are clearly define he culture elements, specifically in organization content. Thus effort by Hostede's and GLOBE project in summarizing culture aspects in which is very abstract in meaning and definition can enhance our understanding in capturing organizational culture elements within organization boundaries.

\section{INDONESIAN'S CULTURAL DIMENSIONS}

This study aimed at looking Indonesian's cultural preferences resulted from national culture dimensions score proposed by Hofstede and GLOBE project and how it affected leadership practices. Secondary data resulted from those two studies are used in order to give analytical discussion in this particular topic (Table 1).

Table 1. National culture score of Indonesia

\begin{tabular}{|c|c|c|c|c|c|c|}
\hline \multirow[t]{2}{*}{ Hofstede Dimensions } & \multicolumn{3}{|c|}{$\begin{array}{c}\text { Score of Indonesian } \\
\text { (Compared with Asian and } \\
\text { World average) }\end{array}$} & \multirow[t]{2}{*}{ GLOBE Dimensions } & \multicolumn{2}{|r|}{ Score } \\
\hline & Indonesia & Asian & World & & Score & World Average \\
\hline Power Distance & 78 & 71 & $\mathrm{n} / \mathrm{a}$ & Group collectivism & 4.41 & $3.52-6.36$ \\
\hline Individualism & 14 & 23 & 43 & Power distance & 5.18 & $3.89-5.80$ \\
\hline Masculinity & 46 & 58 & $\mathrm{n} / \mathrm{a}$ & Humane orientation & 4.69 & $3.18-5.23$ \\
\hline Uncertainty avoidance & 48 & 58 & 64 & Uncertainty avoidance & 4.17 & $2.88-5.37$ \\
\hline \multirow{5}{*}{\multicolumn{4}{|c|}{$\begin{array}{l}\text { measurement } \\
\text { 2. Globe Score } \\
\text { The score is in Globe scale (1-6) measurement }\end{array}$}} & Institutional collectivism & 4.54 & $3.25-5.22$ \\
\hline & & & & Future orientation & 3.86 & $2.88-5.07$ \\
\hline & & & & Performance orientation & 4.41 & $3.20-4.94$ \\
\hline & & & & Assertiveness & 3.86 & $3.38-4.89$ \\
\hline & & & & Gender egalitarianism & 3.26 & $2.50-4.08$ \\
\hline
\end{tabular}

As can be seen from table 1, from the Hofstede study, the score of Indonesian's cultural dimensions is below the average of other Asians nations, where it is contrast to say that, many scholars in the area of organizational studies are believed that perhaps Asians' people are share the similar values. This supported by GLOBE findings, which are more than 10 years later, the values of Indonesians' are remain the same. Indonesians' level on Power Distance, Individualism, Masculinity and Uncertainty Avoidance is low compared with their Asian's nation counterpart. Following discussions are details of some cultural dimensions explained in this study. Moreover, 
In Indonesia, where the Individualism score is relatively low, 14 out of 43 of the world averages, it can also be referred to as collectivist. Furthermore, the GLOBE team found that although this dimension was introduced 25 years ago by Hofstede, the meaning of collectivism has remained the same. In particular this team describes it as in group collectivism (score 4.41 of the world averages of 3.52-6.36).

The level of Masculinity in Indonesia is relatively low, where it scores at 46 of the average of Asian 58 . This dimension is related to the Assertive dimension proposed by GLOBE project where Indonesia scores at 3.86 of average world 3.38-4.49. Another dimensions, is Uncertainty Avoidance, where score of Indonesians' is weak (Hofstede score at 48 and GLOBE project scores at 4.17. Marry and Mansour (2004) found that Uncertainty Avoidance may impact on the degree of formalization and decentralization in organizational structures such as selection practices. It is plausible that appropriate Uncertainty Avoidance practices make it possible for decentralization of operations rather than management by personal control (Marry and Mansour 2004).

When it comes to women emancipation, the level of Gender egalitarianism of Indonesians' is in the average of the world rank. This is particularly true, that the GLOBE project findings illustrated that on average of world gender egalitarianism is $2.50-4.08$, Indonesia is scores at 3.26 .

Indonesians are also often described as friendly, peace loving, and open handed (Mulder 1994). They are concerned about the effect of their actions on the feelings of others and take care not to upset others. This value came through very strongly in the GLOBE studies, with Indonesia score at the 4.69, highest of all countries in the Humane orientation dimension. Showing concern for others, being tolerant of errors, generosity, and sensitivity towards others are behaviors associated with this rating (Hayat and Muzaffer 2004).

\section{UNDERSTANDING ORGANIZATIONAL CULTURE IN INDONESIA}

Indonesians' can be classified as having large-Power Distance, Collectivist, Short-term-orientation, weak Uncertainty-Avoidance, and Feminine culture. This cultural type maintains weak, short term societal ties among organization members and works toward harmonious relationships (Hofstede and Hofstede 2005). This type of company puts group interest above individual interest. Assume that in Indonesia, a group of HR (Human resources) people of a McDonald's restaurant try to introduce the theme called "employee of the month". This is common in an individualist country as a reward of good achievement and performance, where on the other side, in a collectivist country it is very shameful for the people who are selected as employee of the month to wear unusual attributes (such as a hat made from a balloon), as for Javanese-Indonesian people wearing this attribute would mean public embarrassment, or losing face. On the other hand the HR department thought this practice was good and to show to the others, that the employee had a high achievement. This example shows that it is not valid to introduce new values, although they work in some culture, unless we make sure how it is adaptive to the environment in which the organizations operate. Tompenaars and Turner (2004) noted that it would be a serious mistake to assume that the culture preferred in the domestic HR of an international company would work throughout the world and that HR can globalize its various tools without serious problem.

Moreover, as Indonesia uphold the value of collectivism, this in turn affected the employer-employee relationship which is basically moral, like family interaction (Hofstede and Hofstede 2005). In contrast, the employer-employee relationship in the Western management point of view is a contract between parties on a labor market. For example when employees have their family died in workday, it is their obligation to attend the funereal. In Indonesia, obligations to the family in a society are common in ritual ceremonies, like marriages, celebrating seven months of pregnancy (mitoni), and the extremely important act of attending funeral ceremonies (Hofstede and Hofstede 2005). Hofstede argued that this demonstrates the cultural roots of Javanese people's dilemma, where it is the fact that Indonesians like being together and the family network is necessary for their emotional wellbeing.

In regard to assertive behavior, Indonesians' are likely to behave assertive, Hofstede (2005) noted that the Javanese respondent is behaving in an assertive manner. In his example he illustrated the transfer of behavior models from the family to school situation, the teacher being identified as acting as the father in a family setting. It is also notes in this study, that Masculinity is related to demographic aspects, where Deanne argued that people who 
live in South East Asia want to be more assertive, dominant and aggressive, but unfortunately due to the normative values that they have to adopt in their everday life, they couldn't show assertive behavior.

The cultures of different nations may also prefer one corporate culture to another, even within the same multinational company (Trompenaars and Turner 2004). In rewarding employees in person oriented cultures like Indonesia which is characterized by a high level of Power Distance, the reward should be fairly equal and clearly explained, based on the portion of work. Although it is physically seen that the employees did the work, the higher reward should be credited to the manager. That is the hierarchy that distinguishes Indonesian people from other people in a low Power Distance culture. By contrast, in a task-oriented culture like the US, where the level of Power Distance is low, being rewarded as employee of the month when the employee has felt the team has done so much to help and sustain their success, means being embarrassed (Trompenaars and Turner 2004).

In dealing with Indonesians' who avoid uncertainty, a case like expatriate employees who come from countries with strong Uncertainty Avoidance culture like Japan, when working in the Indonesian business environment, which is characterized by weak Uncertainty Avoidance they have to respect the behavior of the major ethnicity who work with them This may frustrate them because usually people from weak Uncertainty Avoidance culture work slowly and with less initiative (Hofstede and Hofstede 2005).

The role of women in Indonesia today is the outcome of a complex mixture of traditional Indonesian custom (tradisi), Moslem law, and more recent social and political developments In Javanese custom it is noted that the woman has more authority, influence, and responsibility than her husband, and at the same time receives more affection and loyalty. The concentration of both of these features in the female role leaves the male relatively functionless in regard to the internal affairs of the nuclear family (Geertz 1961). Recently there is the factor that Indonesia is now in transition to minimize gender differences in work places. It is shown that women's participation in the labor force has increased significantly compared with men's. In 1998, the labor force participation growth rate is was much higher for women (3.7 percent per annum) than for man (2.1 percent) (SEAPAT 1998). Although the majority remains in low skilled work in the industrial sector, the fact is congruent with the GLOBE findings, which shows the Gender Egalitarianism practices are in the mid level.

\section{LEADERSHIP IN INDONESIA}

Managing Indonesian employees is not the same as leading Westerners nor is it the same as managing other Asian employees. To be effective, the leader should encompass the differences of the culture themselves, however, a chosen leadership strategy which may be effective in one culture can be counter-productive in another. Leadership may require an intellectual understanding. Thus the leader may ask them self to consider the importance of cultural attributes for understanding each culture. A country like Indonesia is distinguished by high Power Distance and Collectivism, demanding specific leader treatment. In this setting the leader may play a role in certain ways. In others words, to look at what the impact is of different bundles of cultural dimensions on leadership effectiveness. It may be also necessary to think about the combination of having looked at the cultural dimensions that may impact on the effectiveness of managerial practices

A manager may be aware of the specific influence tactics they should implement, to become an effective leader. Leaders, as well as managers, who will attempt to influence a person from a different culture, may be alert to the occurrence of possible cultural differences. Influence tactics should be viewed from an ethical and cultural perspective. Some tactics may seem ethical, but others may have potential conflict with the cultural norms. In Indonesia that has strong Uncertainty Avoidance, strong influence may be frequent and is a normal feature of life and each day is accepted as it comes. On the other hand, a country with weak Uncertainty Avoidance strong influence may be seen as part of the uncertainty inherent in life which is a continuous threat that must be fought (Hofstede and Hofstede 2005).

For multinational managers who operate internationally it is helpful for them to realize the variety of the human needs regarding their values. It might not be appropriate to look only at the physical aspects of management practices at all, i.e technology, market, etc and economic factors, such as the nation's value that reflects on GDP, GNP etc.; there may also be a requirement to look at the national culture (Hofstede 2006). In Indonesia, where it is 
evident that the GNP is the lowest in the developed world, a global manager should not look at this indicator to treat their employees regarding fair practices in fulfilling employee basic needs, i.e. give a salary that meets the "minimum regional wages". In some cases, it may be better to look at the cultural issues underlying the basic needs of the employee in other ways i.e. social life, such as how employees conduct their social interaction with others in the community. In countries where GNP is low, like Indonesia, it is common that societies tend to put group interest ahead of individual interest. In a collectivist culture like this, good social relationships are more important than money and just paying the wage may not solve the minimum wages problem at all.

Investigation by Hofstede found that leadership styles practiced worldwide should not adapt to the specific leadership styles, which he claimed are more based on Western values and particularly are resulting from US research (Hofstede 2006). Westwood (1997) argued that the leadership styles available in the US are now are being challenged, by the demand for a model that draws in deep-seated and persisting cultural values and assumptions prevailing in other parts of the world. His finding is widely known among leadership theorists as 'headship', which is characterized by distinctive dual formation hierarchy and patriarchal authority with harmony building/maintenance and moral leadership. Looking at the basic national cultural dimensions that generally differ between West and East, it is generally spoken that Eastern people tend to show collectivist behavior, which emphasizes harmony and social order values. Zhou (2006) argued that there are some characteristics of leadership style in Asia, which are authoritarianism, benevolence, and morality. In this type of leadership, the leader may be expected to assert control, build up their authority, and give direction to their employees who are expected to comply respectfully. In particular, showing benevolent behavior, the leader is expected to show their personal caring to each individual privately. In Indonesia, employees expect their leader to not only be a manager, but they are also a protector, a mentor, a father, and must be responsible for them and their extended family (Widyahartono 2007). During the ramadhan month (fasting month) the work hour is reduced from eight hours to six hours, because the employees need to come home earlier to prepare the ceremonial dinner every night during this holy month with their family and extended family. While the modern business world sees this practice is time wasted, and means less production, however, the leader should emphasize this situation in order to maintain their relationship with their employees. Thus, the leaders may put more emphasis on their moral obligation rather than pursuing a role as a real authoritarian leader. Furthermore, the individual repays the benevolence and morality of the leader with gratitude, obedience, respect, and identification.

Moreover, another example that can be considered is the characteristic of paternalistic leadership style found in Indonesia, where Gani (Gani 2004) argued that the leader in an organization in Indonesia has a role as a father who is expected to behave wisely, and honestly. This argument is based on the fundamental deep roots of Javanese culture. Thus, the leader with this certain type of behavior may be expected to be friendly, closely related, and tolerant of their employees. However it does not seem that Javanese leaders have close ties relation at all. In the Javanese leadership history, local leaders derive their authority from many sources, as Cederroth (1994) argued that there are official leaders who acquire most of their authority by virtue of their connections with government authorities. Thus these leaders gain their legitimacy mainly by the favors, material as well as immaterial, which they must deliver to their followers. Because of such assets, personal qualities are comparatively less important for these leaders. However other sources that Cederroth (1994) investigated indicate that local leaders basically have moral influences as a result of their ethical qualities in one way or another, such as by an appeal to the religious yearnings of people. Those two sources of leadership show us how the leaders in Javanese culture maintain their main responsibilities both with the tasks and the people. Thus it may be seen that in the Eastern culture, leaders do not only consider relationships with their people, but they are also responsible for their achievement. Having this situation the leaders in Indonesia may manage effectively by having mutual relationships with their employees, rather than applying certain leadership type that are based on Western perspectives. Furthermore another series of studies in Indonesian culture by (Antlov and Cederroth 1994) found that Indonesians have experienced and accepted organizations with the authoritarian rule and gentle hints, with the characteristic of having a spirit to work with the superior in a patron-clientele relationship system. This characteristic is well rooted in traditional Javanese wisdom and is called "tepa selira" which means mutual respect. Thus, it is the obligation of leaders and followers to make sure their relationships in the organization are based on mutual respect and are well maintained in order to achieve their organization's goals together. 
Although relationships between leadership and culture, as well their linkages, are important to the organization's success, the underlying intercultural connection may differ as a result of national culture. Intercultural connection may have occurred within the national cultural boundaries (Dubrin 2001). An example would be, a US manager in their branch company in Indonesia, which operates in an individualistic, weak Power Distance, weak Uncertainty Avoidance, more feminine, and short-term cultural type. Given this situation, the US manager might have a high expectation that the Indonesian employees would accept their directives immediately, because Indonesians are known to defer to authority. Nevertheless, an Indonesian might need considerable convincing before accepting the authority. Indonesian employees, in general are difficult to be convinced, because they think that the organizations belong to the management or the ruler. There is no obligation for them to have sense of belonging to the organization in which they work. With this example, a global manager has to consider cultural sensitivity that enabled the another to become a multicultural leader.

\section{LESSONS FROM INDONESIA}

The discussion has focused on Indonesian cultural values. The Hofstede's and GLOBE study has investigated cultural values that can contribute to enhance leadership practices and remove barriers related to patronage relationship. On the other hand, recognizing Indonesian's cultural values can direct the managers in generating a leadership style that matches with the Indonesian context.

Expatriate managers working in Indonesia can take advantage of having knowledge of the cultural values that underpin Indonesian's values in the workplace. They have an opportunity to gain insight into Indonesian's values that are considered necessary to create the best leadership style to be effectively implemented in Indonesia (Irawanto 2007). Globalization has made an impact on the workplace environment, such as where many multinational companies opened branch offices in a country like Indonesia, with the manager having different cultural values, i.e. individualism, may impact on the leader-follower relationships. It is generally accepted that many American leadership theories dominates management literature, and there is a danger that this perspective will be adopted as best practice regardless of specific cultural practices applying to different countries (Turner, Trompenaars, 2004). Indonesia's lesson of multiethnic diversity can help to increase understanding, and to respect and value differences in organizations.

The value that Indonesians place on the pursuit of collective and humane- orientation is consistent with these exploratory. To be effective, managers from individualistic and performance orientation cultures need to address Indonesians values, thus gaining insight and acquiring skills that will increase their contribution to effective leadership skills from the local environment, is an important task for them.

\section{AUTHOR INFORMATION}

Dodi Wirawan Irawanto, M.Com., is a senior lecturer in Human Resources Management in Management Department, Brawijaya University, Indonesia. Dodi has served as researcher, trainer in the area of Human Resources Management Development and Leadership Development nationwide. He is a university lecturer who teaches Organization Behavior, Human Resources Management, Leadership, and Change Management. He earned a Master of Commerce degree in Strategic Human Resources Management at Wollongong University, Australia. His area of research's are cross-cultural management, leadership and organizational behavior.

\section{REFERENCES}

1. Alvesson, M. (2000). Understanding Organizational Culture CA, USA, Sage Publications.

2. Antlov, H. and S. Cederroth (1994). Leadership on Java: Gentle hints, authoritarian rule. Surrey, UK, Curzon Press Ltd.

3. Bjerke, B. (1999). Business Leadership and Culture; National management styles in the global economy. MA, USA, Edwar Elgar Publishing, Inc.

4. Cederroth, S. (1994). New order modernization and Islam. Leadership on Java: Gentle hints, authoritarian rule. H. Antlov and S. Cederroth. Surrey, UK, Curzon Press Ltd. 
5. Deal, T. E. and A. A. Kennedy (1982). Corporate Cultures: The rites and rituals of corporate life, Reading Mass, Addison-Wesley.

6. Dubrin, A. J. (2001). Leadership; Researh findings, practice, and skill. NY, USA, Houghton Mifflin.

7. Gani, D. S. (2004). Leadership in Indonesia:A case for managing relationship within organizations. Leading in High Growth Asia: Managing relationship for teamwork and change. D. Tjosvold and K. Leung. Singapore, World Scientific Publishing Co.Pte.Ltd.

8. Geertz, H. (1961). The Javanese Family: A Study of Kinship and Socialization. New York, Free Press.

9. $\quad$ Hatch, M. J. and M. Schultz (1997). "Relations between organizational culture, identity and image." European Journal of Marketing_31(5).

10. Hayat, K. and B. Muzaffer (2004). Humane Orientation in Societies, Organizations, and Leader Attributes. Culture, leadership, and organizations : the GLOBE study of 62 societies / edited by Robert J. House. R. J. House, P. J. Hanges, M. Javidan, P. W. Dorfman and V. Gupta. CA, USA, Sage Publications.

11. Hofstede, G. (2006). "What did GLOBE really measure? Researchers' minds versus respondents' minds." Journal of International Business Studies 37.

12. Hofstede, G. H. and G. J. Hofstede (2005). Cultures and organizations : software of the mind. NY, USA, McGraw-Hill.

13. House, R. J., Ed. (2004). Culture, leadership, and organizations : the GLOBE study of 62 societies _ edited by Robert J. House. CA, USA, Sage Publications.

14. Irawanto, D. (2007). "National Culture and Leadership: Lesson from Indonesia." Journal of Business and Management Eksekutif 4(3).

15. Lees, S. (2003). Global Acquisitions; Strategic integration and human factor. NY, USA, Palgrave Macmillan.

16. Marry, S. D. L. and J. Mansour (2004). Uncertainty Avoidance. Culture, leadership, and organizations : the GLOBE study of 62 societies / edited by Robert J. House. R. J. House, P. J. Hanges, M. Javidan, P. W. Dorfman and V. Gupta. CA, USA, Sage Publications.

17. Martin, J. (2002). Organizational Culture; Mapping the terrain. CA, USA, Sage Publications Inc.

18. Mulder, N. (1994). The Ideology of Javanese-Indonesian Leadership. Leadership on Java: Gentle hints, authoritarian rule. H. Antlov and S. Cederroth. Surrey, UK, Curzon Press Ltd.

19. Peters, T. J. and R. H. Waterman (2004). In Search of Excellence : Lessons from America's best-run companies. New York, USA, Harper Business Essentials.

20. Schein, E. H. (1999). The corporate culture survival guide : sense and nonsense about culture change. CA, USA, Jossey-Bass.

21. SEAPAT, I. L. O. (1998). Gender Issues inTthe World of Work: Labour market gender issues by country Indonesia

22. Triandis, H. C. (2004). "The Many Dimensions of Culture." Academy of Management Executive 18(1).

23. Trompenaars, F. and C. H. Turner (1998). Riding The Waves of Culture; Understanding cultural diversity in global business. NY, USA, McGraw-Hill.

24. Trompenaars, F. and C. H. Turner (2004). Managing People Across Culture. West Sussex, England, Capstone Publishing Ltd.

25. Westwood, R. (1997). "Harmony and Patriarchy: The Cultural Basis for `Paternalistic Headship' Among the Overseas Chinese." Organization Studies (Walter de Gruyter GmbH \& Co. KG.) 18(3): 445.

26. Widyahartono, B. (2007). Telaah Kepemimpinan Efektif. Antara News.

27. Zhou, J. (2006). "A Model of Paternalistic Organizational Control and Group Creativity." National, Culture, and Group; Research and managing groups and teams. 